\title{
入院調剂時における内服用楽剤の剤形変更に関する考察
}

\author{
倉本加代, 小滝 一 \\ 東京大学医学部附属病院薬刻部*
}

\section{Alteration of Dosage Forms in Dispensing of Oral Drug Products for Inpatients}

\author{
KAYO KURAMOTO and HAJIME KOTAKI \\ Hospital Pharmacy, Faculty of Medicine, University of Tokyo*
}

(Received April 23, 1985)

\begin{abstract}
The present situation of the alteration of dosage forms in dispensing of oral drug products for inpatients at the hospital was studied. The alterations of dosage forms involved are as follows: tablets and capsules intended for constitution as powders; tablets, powders and capsules as liquids; tablets and powders as capsules. The total number of the oral drug products prescribed for 3 months was 41,926 , including 667 for alterations. The alterations consisted of 69 $\%$ for grinding of tablets for constitution as powders, $23 \%$ for dissolution of powders as liquids, $4.9 \%$ for opening of capsules as powders, and $1.8 \%$ for capsule-filling of powders. Fifty-seven percent of the alterations were made for securing a substitute route for oral administration of tablets and capsules in patients treated by the administration through tubes terminating in the stomach.

On the basis of the results of this study, several problems caused by the alteration were discussed, such as loss in weight of tablets on sieving after grinding, method of preparation of liquid products from tablets or powders for the patients administered through the tube, and changes in bioavailability of drugs by the alteration.
\end{abstract}

Keywords_-alteration; dosage forms; oral drug products; dispensing; inpatients; ground tablets; opened capsules; capsule-filling; liquid preparations

調剤を行ら上で錠剤を粉砕したり，カプセル剤を開封 しなければならないことがあり，昭和46年に行われた全 国 163 病院の調査結果には, $96.3 \%$ 病院で錠 剤の 粉 砕, 95.9\%の病院でカプセル刻の開封が行われているこ とが示されている.1

処方せんに基づいて調剤する場合，処方医の指示する 剤形が最優先され，その指示がない場合にはその施設の 内規に従って剂形の選択がなされる。しかし，目的とす る剤形が市販されていない場合，あるいは市眅されてい

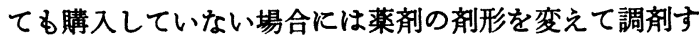
ることになる．本報告では，内服用の錠剤の粉碎または カプセル郕の開封による散剂化, 粉砕した錠剤, 開封し

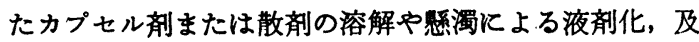

* 東京都文京区本郷 7 丁目 3-1；3-1, Hongo 7chome, Bunkyo-ku, Tokyo, 113 Japan
び錠剤をそのまま，または散鼡をカプセルに充填するカ プセル剤化を凧形変更とする (困 1 ).

剤形を变える場合に，単に粉末にする目的で錠剤の粉 砕やカプセル㶡の開封などを行うことがある。しかし不 注意にそれを行らと，不快な味または臭いの防止，吸湿 の防止などの目的で糖衣やフイルムの剂皮が施された製 剤や，腸容化あるいは徐放化するために加工された製剤 においては，その特性を無視することになる。また風形 変更には, 薬剤の物理化学的変化や生物学的利用性など に関する事がらが含まれており，剤形変更の実態を把握 することは重要である.この実態に関しては二, 三の報 告2,3) があるが，いずれる外来処方せんと入院処方せん を総計して解析している.剂形変更の実態は, 患者の重 症度により処方内容に違いがある外来処方せんと入院処 方せんとに分けて検討することが必要である.

本報告では, 東京大学病院の入院処方せんにおける剤 


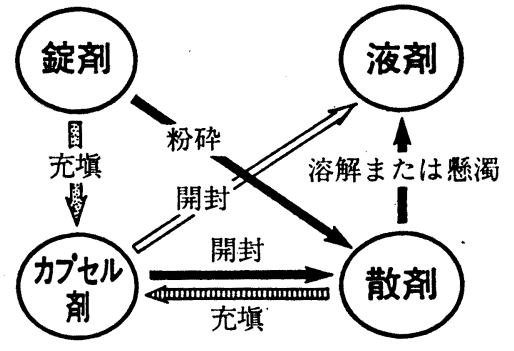

図1. 調剤時の内服用薬郕の剂形変更

形変更の実態を調查し, 得られた知見に基ついて成形変 更に伴う問題について考察する.

\section{调查方 法}

23診療科全部, 救急部及び隔離病棟の入院患者におけ る内服用薬剤が記載されている入院妈方せんを調査対象 にし, 剤形を変更して調剂した内服用薬阂の品名, 品目 数及びその延べ数, 及び診療科別による斉形変更の頻度 を調べた．調査期間を設定するために, 予め過去 3 年間 の月別の処方せん枚数を調査した. その結果, 2 月, 3 月の処方せん枚数がほぼ年間の月当りの平均值を示すこ とがわかった，そこで，昭和59年 2 月と 3 月を選び，さ らに入院患者の大部分が入れかわると思われた同年 8 月 を選んだ.それらの月の処方せん枚数は，2月 の 5,405 枚 (内服用薬剤の延べ数として 14,574 )， 3 月の 5,503 枚 $(13,665)$ 及び 8 月の 5,497 枚 $(13,687)$ で, 計 16,405 枚 $(41,926)$ であった. 剂形の変更理由の確認は, 処方 医に問い合わせて行った.

\section{結 果}

\section{用形变更の品目数及びその延べ数}

調查した処方せん中の内服用薬剤の総品目数は計 826 であり，このうちの83品目 (10\%) が剂形を変えて調剂 された。その剤形変更した品目の総延べ数は 667 で，こ れは内服用薬剤の品目の総延べ数の $1.6 \%$ に相当した.

剂形を変更した上記の計 83 品目のらち，2 月と 3 月の 2 カ月間にわたって重複していた品目数は30（36\%)で あった．これに比べて 2 月と 8 月，及び 3 月と 8 月での それは各々 $19(23 \%)$ と20 (24\%) に減少した.この理 由は，入院患者の入れかわりにより処方内容が変ったた めであると考えられる．一方， 2 月， 3 月及び 8 月の 3 カ月間にわたって重複していた品目数は17（20\%）で, それらはビンルボン®錠, プロタノール®錠, ウブレチ ド® 錠, サラゾピリン®錠, パナルジン®錠, ヒダント 一ルF錠, プルゼニド®錠, ザイロリック®錠, フェス タール®錠, ダーゼン®錠, チウラジール®錠, カルニ
表 1. 東京大学病院の入院処方せん中の郕 形変更承品名とその延へ数 （明和59年 $2,3,8$ 月の処方せん）

表1-1．錠郕を粉砕して散剤にした薬品名と延べ数

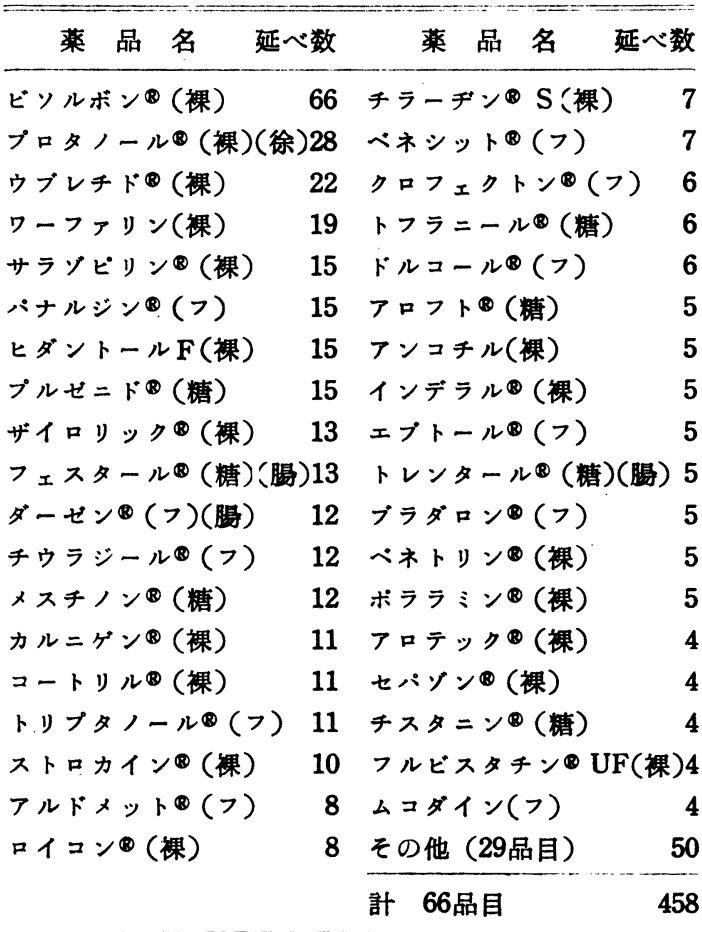

（裸）裸錠; (糖)糖衣錠;（フ）フイルム錠;（徐)徐放 錠；（腸）晹溶錠

表 1-2. カブセル刻を開封して散㓣にした 薬品名と延べ数

\begin{tabular}{|c|c|c|}
\hline 薬 & 品 名 & 延べ数 \\
\hline \multicolumn{2}{|c|}{ エンピナース・ P(渴) } & 10 \\
\hline \multicolumn{2}{|c|}{ リファシン } & 8 \\
\hline \multicolumn{2}{|c|}{ リスモダン® } & 7 \\
\hline \multicolumn{2}{|c|}{ オイテンシン(徐) } & 4 \\
\hline \multicolumn{2}{|c|}{ オノブローセ゚®S A (渴) } & 2 \\
\hline \multicolumn{2}{|c|}{ カナマイシン } & 1 \\
\hline \multicolumn{2}{|c|}{ ニフラン® } & 1 \\
\hline 計 & 品目 & 33 \\
\hline
\end{tabular}

(腸)腸溶性カブセル刻; (徐)徐放性カプセル郕

ゲン®錠, トリプタノール®錠, エンピナース・Pカプ セル,エブトール®錠, 塩酸モルヒネ(末), 及び塩酸コ カイン (末) であった.これらの薬剤は剤形変更の対象 になりやすいことを示している.

錠绪及びカプセル都の数都化 
表 1-3，散用を水に溶解して液刜にし た薬品名と延べ数

\begin{tabular}{cc}
\hline 薬 品 名 & 延べ数 \\
\hline 塩酸モルヒネ & 80 \\
塩酸コカイン & 64 \\
硫酸マクネシゥム & 9 \\
D-ソルビトール & 2 \\
\hline 計 4 品目 & 155 \\
\hline
\end{tabular}

表 1-4. 散鼡をカプセルに充塤してカプセ ル用にした薬品名と延べ数

\begin{tabular}{|c|c|c|}
\hline 薬 & 品名 & 延べ数 \\
\hline \multicolumn{2}{|c|}{ ロイケリン® } & 5 \\
\hline \multicolumn{2}{|c|}{ 炭酸水素ナトリウム } & 4 \\
\hline \multicolumn{2}{|c|}{$\mathrm{P}-\mathrm{A} \mathrm{D}^{*}$} & 1 \\
\hline \multicolumn{2}{|c|}{ タンニン酸フルブミン } & 1 \\
\hline \multicolumn{2}{|c|}{ ロートエキス } & 1 \\
\hline \multicolumn{2}{|c|}{ 計 5 品目 } & 12 \\
\hline
\end{tabular}

*当院の約東処方で $3 \mathrm{~g}$ 中にタンニン酸了 ルブミン $1 \mathrm{~g}$, 乳酸カルシウム $1 \mathrm{~g}$, 天 然ケイ酸フルミニウム $1 \mathrm{~g}$ を含む散郕

剂形を変更した83品目のらち，鎔剂を粉碎して散剤に する例が最す多く，その品目数は66 (80\%) であり，延 べ数として 458(削形変更総延べ数の69\%) であった（表 1-1). 上記の66品目の5ち裸錠は35品目, フイルムュー ティング錟は19品目，及び糖衣鎰は12品目であった。こ れらのらち徐放性，腸溶性の錠剤が 6 品目あった。ビソ

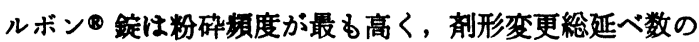
$9.9 \%$ を占めていた. なお，この薬用はその後に細粒が 発売されたため, 現在はその細粒を取り扱っている.

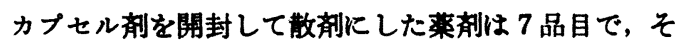
の延べ数は33 (4.9\%) であり（表 1-2)，これらはいず れる開封して内容物をそのまま分包したるのであった。

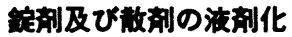

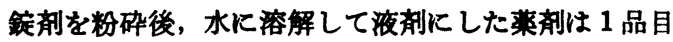
で，硫酸ポリミキシンB溶性錠であった，その延へ数は 9 (1.3\%) であった.

散郕を水に溶解して液用にした乘郕は 4 品目で，その 延べ数は155（23\%）であった(表 1-3). このうちの144 (93\%) が塩酸モルヒネと塩酸コカインであり，いずれ る溶解してブロンプトンミクスチャーにする処方であっ た. その処方において，塩酸モルヒネに塩酸コカインを 配合した例は64，塩酸モルヒネのみの例は16であった。
なお上記の散剤化，及び液剤化を行った錠剤とカプセ ル剤の計74品目のうちの44品目 (59\%) については，そ の散剤や液戍が市販されていない薬剤であった.

\section{敬戍のカブセル詴化}

散剤をカプセルに充填してカプセル剤にした薬剤は 5 品目で，その延べ数は11（1.6\%）であった（表 1-4). これらは散郕の服用を拒否する患者に投与するためで， いずれる小児科の処方せん記載の薬剤であった.

\section{玮形变贡の理由}

剤形の変更を必要とした理由を医師に問い合わせた結 果を表 2 亿示す. 最も多かった理由は，4藏以上でも錠 ・カプセル剤の服用が困難な場合で，その延べ数は 389

表 2. 剤形変更理由とその延べ数

\begin{tabular}{|c|c|}
\hline 理 & 延べ数 \\
\hline 4 歳以上で錠・カプセル郕の服用が困難 & 389 \\
\hline ブロンプトンミクスチャーの調製 & 144 \\
\hline 4 歳末満で錠・カブセル剂の服用が困難 & 52 \\
\hline 適切な含量の錠㓣がない & 44 \\
\hline 味が㩊い & 22 \\
\hline 用量変更を隐べいする & 11 \\
\hline 大きい䥓㓣の服用が困難 & $\mathbf{5}$ \\
\hline 計 & 667 \\
\hline
\end{tabular}

表 3. 彭療科別による形剤変更延べ数とその割合

\begin{tabular}{|c|c|c|}
\hline 部㟟 科 & 延べ数 & 剤形変更の割合(\%)* \\
\hline 神経内科 & 151 & 7.4 \\
\hline 胸部外科 & 96 & 2.6 \\
\hline 小児 科 & 88 & 5.9 \\
\hline 第三内科 & 58 & 1.9 \\
\hline 放射線科 & 45 & 4.4 \\
\hline 耳艒咽喉科 & 29 & 1.4 \\
\hline 第一外科 & 27 & 1.6 \\
\hline 第二内科 & 27 & 1.2 \\
\hline 第二外科 & 23 & 1.0 \\
\hline 瞱・神経外科 & 21 & 1.3 \\
\hline 物療内科 & 20 & 0.6 \\
\hline 隔離病楝 & 19 & 1.0 \\
\hline 老人科 & 13 & 1.2 \\
\hline 整形外科 & 12 & 1.4 \\
\hline 第一内科 & 12 & 0.4 \\
\hline 小児外科 & 11 & 2.2 \\
\hline 精神神経科 & 11 & 0.4 \\
\hline
\end{tabular}

*（各科における風形変更延へ数）/(各科における 内用薬郕䌊䃌べ数) $\times 100$ 
であった.これは総延べ数 667 の58\%に相当した。この らちの $98 \%$ ，経鼻胃用カテーテルを利用して薬剤を投 与（経管投与）する例であった．また，患者の治療上そ の用量の変更を故意に処方医が隐した例は11であり, 精 神科に多かった.

剂形変更の多い主な診療科は, 神経内科, 胸部外科, 小児科であった (表 3 ).この理由は神経内科では長期入 院を必要とする重症患者が多く，そのために程管投与を 必要とすることが多いこと，胸部外科では手術後汇経管 投与を必要とする患者が他の科より多いためであった． また，小児科で多かったのは，たとえばプロタノールの 錠やインデラル錠のように小坚を対象にした含量の錠 凨がないためであった．ちなみに当院の外来処方せんに おける昭和54年の調査では，4) 錠剂の粉砕とカプセル剂 の開封例は小児科処方せんに最も多く，総延べ数の $91 \%$ であり，つぎに多かったのが精神科の $3 \%$ \%゙った。

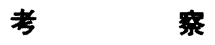

\section{錠郕及びカプセル绪の散刜化}

錠剤の粉砝飞伴ら生物学的利用性の変化は重要であ り，それによって治療上効果が得られなかったり，中毒 が発現する恐れがある．たと觉ばチオリダジン,゙) ジピ リダモール, 尚 ジゴキシンク) などの錠剤を粉碎して投与. すると，錠剤投与時に比べて血中濃度が高くなることが 報告されている．今回の調査において，英国薬学会が生 物学的利用性汇問題があると指摘した薬物, ${ }^{81}$ 及び米国 の FDA が「生物学的同等性の資料の要求」に挙げた薬 物 ${ }^{9}$ 飞該当する含有薬剤は, プロタノール 錠（塩酸イ ソプロテレノール), ワーファリン錠（ワルファリンカ リウム), ヒダントール F 錠 (フェニトイン), チウラジ ール®錠（プロピルチオウラシル）, コートリル@錠（ヒ ドロコルチゾン), トリプタノール®錠（塩酸アミトリプ チリン), ベネシット®錠 (プロベネシド), トフラニー ル®錠（塩酸イミプラミン）, フルビスタチン®UF錠 (グリセオフルビン), プレドニン®錠（プレドニゾロ ソ), フルイトラン®錠 (トリクロルメチアジド), ジフ ベン®錠 (トルブタミド), テオナ® $\mathrm{P}$ 錠（テオフィリ ン）及びメドロール®錠（メチルプレドニゾロン）の14 品目であった. フェニトインの錠剤は，粉碀して投与し てす錠剤投与時とほぼ同し濃度推移を示すので, 10) それ ほど問題はないと思われる。しかし，その錠剤と市販散

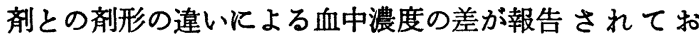
り,11) 錠剂粉砕の指示がある場合に市販散剤を用いるこ とは十分慎重に行われなければならない。

調查結果の中で，腸溶性の錠剤・カプセル剤としてフ
エスタール®錠, ダーゼン®錠, トレンタール®錠, エ ンピナース® P カプセル及びオノプローゼ・ S A カプセ ルの 5 品目, 徐放性の錠剂・カプセル剂はプロタノー ル®錠, ヘルベッサー®錠, テオナ®P $\mathrm{P}$ 錠及びオイテン シンカプセルの 4 品目が認められた。.このような錠片の 粉䂶やカプセル阂中の顆粒の粉碀は，腸溶性化や徐放性 化した特性を無視することになり，ひいては生物学的利 用性が大きく变化することが考えられる．たとえば，錠 剤中にテオフィリンの顆粒を含む小児用の徐放性製剤で

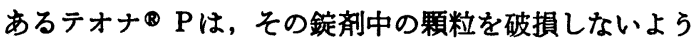
に注意して砕いても，その徐放性がほとんど失われるこ とが溶出試験, ${ }^{12)}$ 及びヒトへの投与試験13)により示され ている.腸溶性のダーゼンの錠には主成分としてセラぺ プターゼが含有されている．この酵素は $37^{\circ} \mathrm{C}$ において，

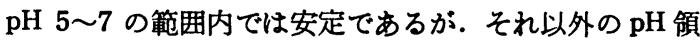
域では急速に失活する14)ので, 粉研して投与すると胃内 での低い $\mathrm{pH}$ により失活することが考えられる。また， フェスタール®錠, エンピナース®P カ カプセル及びオ, プローゼ『S A カプセル中に含まれる酵素も胃内の低い $\mathrm{pH}$ により失格することが考えられる.

錠剤粉碎時には重量の目隇りる問題になる．粉碀時の 錠数が少ないほど目減り率が大きいことが報告されてい る.16) 当院では乳鉢または錠剤粉碎機を用いて錠倣を粉 砕したのち，さらに粒子を整えるために32×ッシュのふ るいを通している.しかし、フイルムコーティンクされた パナルジン®錠は郕皮との結合が強いためにその分離が 容易でなく，乳鈢内での粉碎の程度によってはふるい上 にかなり残存するので，粉碚時には特に注意を要する.

投与量の愊や錠郕の大きさが問題になることがある. たとえば,プレドニゾロンのように投与量範囲が広い薬 剤では，市販の 100 倍散を用いると処方量によっては种 取量が大きくなるため，錠威を粉砕することになる，サ ラゾピリン®錠は直径 $13.6 \mathrm{~mm}$ の大きな錠剤であるこ とから，患者によっては服用できず，粉碎することにな ろ.

\section{錠威及び散绪の液绪化}

錠凧の粉碎に次いで多かった剤形変更延べ数は散昘の 液剤化であり，その大部分はブロンプトンミクスチャー の調製のために塩酸モルヒネ, 及び塩酸コカインを溶解 するすのであった. ブロンプトンミクスチャー中でのコ カインの安定性に関しては, $\mathrm{pH} 3.0 \sim 3.5$ で最す安定で あり, また単シロップ濃度, 及びフルコール莀度の変化

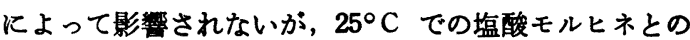
共存下ではコカインの分解が顕著になることが報告され ている. ${ }^{18)}$ 一方, $25^{\circ} \mathrm{C}$ での緩衡液 $(\mathrm{pH}$ 6.8) 中におい 
て、 コカインは 1 週間で約 $50 \%$ が分解することが報告さ れている. ${ }^{17)}$ ブロンプトンミクスチャーには種々の変形 処方があり，18,19) 塩酸コカインが配合された場合，溶液 の $\mathrm{pH}$ に注意する必要があろう。

ポリミキシンB溶性錠は，その苦味のために患者が服 用を拒否することが多い，そのために錠郕を粉砕し，単 シロップを加えた液剤にする指示が多い，しかし，単シ ロップを加えてもその味はありり改善されないので，イ ンスタントココアを加える20)など苦味を抑える工夫が必 要であろう.なお，今回の調査期間中にはなかったが， ポリミキシンB溶性錠をカプセルに充填して調郕するこ ともまれにある。

\section{制形変更の理由}

剤形変更を必要とした理由として最も多かったのは， 経管投与のためであった．経管投与は，通常直径 $2.5 \mathrm{~mm}$ 以下のポリェチレン製の管を使用して，調剤された薬剤 を水に眯濁あるいは溶解して投与寸るので，容易に管を 通ることが前提になる．当院ではコランチル 顆粒やり ルヘンン®顆粒などす，粉砝せずとそのまま調剤してい る. しかし経管投与の場合，病棟では顆粒剤も粉砕して 投与することが多く，オイテンシンカプセル中の徐放性 顆粒もその例外ではない。この場合には徐放性顆粒を用 いる必要性の有無が疑問である。一方，管への通りが非 常に困難な細粒としてペングロープ®がある．この細粒 は管内で凝集してしまうので，錠剤を粉碎して調郕して いる. 経管投与ができる散剤や細粒郕の開発が望まれ る.また，バルューせ゚ 顆粒は粒子が大きくて管を通ら ないので調剤室で粉确している，しかし，この顆粒には カルボキシメチルセルロースナトリウムが含有されてい るために粉末化して水を加えて䅗濁液を調製すると, 容 易に水になじまずに大きな塊になる，病棟では，揊汼し ながら少しずつこの粉末を加えて懸濁している.

版形変更に伴う問題は上記のように多い。しかしなが ら，現在までに剤形変更の可否に関してまとめたるのは ほとんどなく, 21,22) その可否を判断する上で参考になる のは水野らの報告21)だけであろら：また日常業務におい て, 薬郕の添付文書を利用することが多いが，鼡形変更 に関する情報が記載されている例が少ないことを痛感し ている. 少なくとも市眅されている用形が 1 種類の薬郕 に関しては，その添付文書中に郕形変更の可否や注意事 項の記載が望まれる.

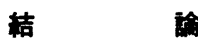

1. 当院の入院調剤時の剂形变更は, 錠剤の散剤化の 例が最も多く，次いで散剤の液刻化，カプセル剂の散阂
化，散剤のカプセル剤化の順であった。

2. 経管投与のための剂形変更が最も多く, 変更理由 の大半を占めることがわかった。

3. 郕形変更を伴う問題として, 粉碎時の重量の目減 り, 経管投与の場合の液剤の調製方法, 及び剤形を変え ることによる生物学的利用性の変化などがある. 今後そ れらを十分に検討した上で調剤方法を確立しなければな らない。

\section{引用 文 城}

1）福島広利, 宇野豊三, 黒田耕司, 信藤緑, 中村繁 一: 薬珮学, 32, 別冊付録 4 (1972).

2）石動谷正博，杉田由紀夫，寺沢孝明，馬場勇：日 薬誌, 19, 521 (1983).

3）幸保文治：薬事新報， 712, 528 (1973).

4) 内坦節夫, 小林節子：私信.

5) T.J. Mellinger : Amer. J. Psychiatry, 121, 1119 (1965).

6) T.J. Mellinger and J.G. Bohorfoush : Arch. Int. Pharmaco-Dyn., 163, 471 (1966).

7) T.R.D. Shaw, M.R. Howard and J. Hamer : Lancet, 2, 303 (1972).

8）鈴木德治 : “薬物のバイオフベイラビリティ,”楽 業時報社, 東京, 1978, pp. 39-48.

9）鈴木徳治：月刊薬事，26，1697 (1984).

10) Y. Kohda, K. Nishihara, Y. Saitoh, F. Nakagawa, Z. Tamura, A. Hosaka and N. Ishikawa : J. Pharmaco-Dyn., 6, 752 (1983); 西 原カズョ，幸田幸直：私信.

11）福山幸夫：脳と発達， 10，94 (1978).

12）大菻直子, 飛野幸子, 岩奥椧子, 中野真沉 : 医学 のありみ, 129, 27 (1984).

13）中園直子，猪爪信夫，飛野幸子，岩奥珨子，中野 真沉：臨床薬理, 16, 401 (1985).

14）宮田孝一：武田研究所報, 31,375 (1972).

15）桑名由紀子, 平松弘子, 古市勝久, 住田克己: 病 院薬学, 4, 16 (1978).

16) G.K. Poochikian and J.C. Cradock: J. Pharm. Sci., 69, 637 (1980).

17) J.B. Murray and H.I. Al-Shora: J. Clin. Pharmacy, 3, 1 (1978).

18）保田静江, 武藤正, 中岡洋子，山下朋子，岡村好 孝: 病院薬学, 8,222 (1982).

19）堀岡正義編：“DI 実例集 (5),”薬業時報社, 東 京, 1984, pp. 254-256.

20）堀岡正義編：“DI 実例集（4)”. 薬業時報社, 東 京, 1984, pp. 246-247.

21）水野恵司, 瀬戸吉郎, 阿部和史：都菜誌, 32, 160 (1983).

22) J.W. Long: "Clinical management of prescription drugs," Harper \& Row Publishers, Philadelphia, 1983. 